\title{
Molecular diversity of Mycobacterium tuberculosis strains in a slum area of Rio de Janeiro, Brazil*
}

\author{
Diversidade molecular de cepas de Mycobacterium tuberculosis \\ em uma região de favela da cidade do Rio de Janeiro
}

\author{
Joycenea Matsuda Mendes' ${ }^{1}$ Silvia Maria Almeida Machado $^{2}$, Maria Cristina Lourenço ${ }^{3}$, \\ Rosa Maria Carvalho Ferreira ${ }^{4}$, Leila de Souza Fonseca ${ }^{5}$, Maria Helena Feres Saad ${ }^{6}$
}

\begin{abstract}
This retrospective molecular study involving restriction fragment length polymorphism, using insertion sequence 6110 as a marker, was conducted in order to provide an initial insight into the genetic diversity of Mycobacterium tuberculosis strains isolated in the slums of the Complexo de Manguinhos, located in the city of Rio de Janeiro, Brazil. Of the 67 strains evaluated, 23 (34.3\%) were found to belong to clusters (total clusters, 10). Household and social chains of transmission were associated with clustering, in $20 \%$ and $60 \%$, respectively. Living in the Conjunto Habitacional Programado 2 slum was associated with clustering. Although not significant, it is relevant that $26 \%$ of the clustered strains presented primary resistance. These findings, although possibly underestimating the prevalence due to the failure to analyze all strains, could help improve the local tuberculosis control program.
\end{abstract}

Keywords: Tuberculosis; Epidemiology, molecular; Mycobacterium tuberculosis/transmission; Polymorphism, Restriction Fragment Length.

\section{Resumo}

Este estudo retrospectivo envolvendo polimorfismo de fragmento de restrição e utilizando como marcador a seqüência de inserção 6110 , foi realizado para fornecer informações iniciais quanto à diversidade genética das cepas de Mycobacterium tuberculosis isoladas em favelas do Complexo de Manguinhos, na cidade do Rio de Janeiro. Das 67 cepas isoladas, 23 (34,3\%) foram agrupadas em clusters (total de clusters, 10). A transmissão entre comunicantes domiciliares e extra-domicialiares estave associada a $20 \%$ e $60 \%$ dos clusters, respectivamente. Ser morador do Conjunto Habitacional Programado 2 foi associado à presença de clusters. Embora não significativo, é relevante o fato de que 26\% das cepas em cluster apresentaram resistência primária. Estes achados, embora possivelmente subestimados devido à impossibilidade de analisar todas as cepas, fornecem subsídios para a melhoria do programa local de controle da tuberculose.

Descritores: Tuberculose; Epidemiologia molecular; Mycobacterium tuberculosis/transmissão; Polimorfismo de Fragmento de Restrição.

\footnotetext{
* Study carried out at the Oswaldo Cruz Institute Foundation, Rio de Janeiro. Brazil.

1. Public Health Physician. Centro de Pesquisa Leônidas \& Maria Deane/Fundação Instituto Oswaldo Cruz - CpLMD/Fiocruz, Leônidas \&t Maria Deane Research Center/Oswaldo Cruz Institute Foundation - Manaus (AM) Brazil

2. Biotechnologist III in the Laboratory of Cellular Microbiology. Fundação Instituto Oswaldo Cruz - Fiocruz, Oswaldo Cruz Institute Foundation - Rio de Janeiro (RJ) Brazil.

3. Full Researcher in the Department of Bacteriology. Instituto de Pesquisa Clínica Evandro Chagas/Fundação Instituto Oswaldo Cruz - IPEC/Fiocruz, Evandro Chagas Institute of Clinical Research/Oswaldo Cruz Institute Foundation - Rio de Janeiro (RJ) Brazil.

4. Pharmaceutical Biochemist in the Department of Bacteriology. Fundação Instituto de Pesquisa Clínica Evandro Chagas/Instituto Oswaldo Cruz - IPEC/Fiocruz, Evandro Chagas Institute of Clinical Research/Oswaldo Cruz Institute Foundation - Rio de Janeiro (RJ) Brazil.

5. Full Professor in the Laboratory of Mycobacteriology. Institute of Microbiology/Universidade Federal do Rio de Janeiro - UFRJ, Federal University of Rio de Janeiro - Rio de Janeiro (RJ) Brasil.

6. Full Researcher III in the Laboratory of Cellular Microbiology. Fundação Instituto Oswaldo Cruz - Fiocruz, Oswaldo Cruz Institute Foundation - Rio de Janeiro (RJ) Brazil.

Correspondence to: Maria Helena Féres Saad. Laboratório de Microbiologia Celular, Instituto Oswaldo Cruz/Fiocruz, Av. Brasil, 4365, CEP 21045-900, Rio de Janeiro, RJ, Brasil.

Tel 5521 2598-4346 E-mail: saad@ioc.fiocruz.br

Financial support: The study received financial support from the Conselho Nacional de Desenvolvimento Cientifico e Tecnológico (CNPq, National Council for Scientific and Technological Development; Millennium Institutes Project), the Rede Brasileira de Pesquisas em Tuberculose (Rede TB, Brazilian Tuberculosis Research Network) and the Fundação Carlos Chagas Filho de Amparo à Pesquisa do Estado do Rio de Janeiro (FAPERJ, Carlos Chagas Filho Foundation for the Support of Research in the State of Rio de Janeiro, Brazil).

Submitted 7 February 2008. Accepted, after review, 24 April 2008.
} 
Tuberculosis (TB) remains a disease associated with overcrowding, poor nutrition and poor housing, occurring primarily in developing countries. Nevertheless, as long as there are individuals with active TB, Mycobacterium tuberculosis will prevail in the world, since, due to its airborne nature, the transmission of TB encounters few barriers inhibiting broad dissemination within the community.

Brazil occupies the 22nd position in global incidence rates of TB. Most $(39,836)$ of the new cases of TB in Brazil have been reported in the southeastern region, and the state of Rio de Janeiro is the second largest contributor in that region, with a rate of 99/100,000 population. ${ }^{(1,2)}$ However, in some low-income Rio de Janeiro communities, such as Complexo de Manguinos (CM), an urban area composed of 12 slums, the rate exceeds 150/100,000. According to previous studies, ${ }^{(3,4)}$ cases of TB in this area were concentrated in two of the slums, Conjunto Habitacional Programado 2 (CHP2), and Parque Carlos Chagas, the two poorest communities of the area, from 1986 to 1994, whereas, from 2000 to 2002, the incidence in those two slums, although still high, declined, and similar or higher rates emerged in other slums, suggesting that $\mathrm{TB}$ continues to be endemic in the area, making it an interesting target for epidemiological studies.

Located Área Programática 3.1 (AP-3.1, Health Care Zone 3.1), ${ }^{(2)}$ which is situated in the north zone of the city of Rio de Janeiro, CM has 42,100 inhabitants distributed approximately in 8,000 dwellings with approximately five persons per dwelling. The Tuberculosis Control Program (TCP) in this area operates out of the Centro Saúde Escola Germano Silval Faria/Escola Nacional de Saúde Pública/Fundação Oswaldo Cruz (CSEGSF/ENSP/Fiocruz, Germano Silval Faria College Health Care Center/National College of Public Health/Oswaldo Cruz Foundation). The CSEGSF serves the CM population as a priority and is integrated into the Family Health Program. The TCP provides bacillus Calmette-Guérin vaccination and passive case finding. In the present study, retrospective molecular typing of $67 \mathrm{M}$. tuberculosis isolates, based on restriction fragment length polymorphism (RFLP), was applied in order to provide an initial insight of TB transmission in this area. ${ }^{(5,6)}$ The samples were obtained from a previous study ${ }^{(7)}$ and represent $31 \%$ of all cases diagnosed between October of 2000 and December of 2002.
The use of DNA fingerprinting yielded ten clusters, comprising $23(34.3 \%)$ of the 67 strains. Among those 23 strains, the RFLP-pattern presented 100\% and 95\% similarity, respectively, in 16 and 7. The majority of the clusters exhibited an insertion sequence 6110 (1S6110) copy number ranging from 8 to 16 (mean, 11) and only one cluster exhibited 2 copies of 1S6110. Patient ages ranged from 18 to 77 years (mean, $36 \pm 14$ years), and 65.7\% were male. All patients had been tested for HIV, and 6\% were seropositive.

Clinical and demographic characteristics of patients analyzed by risk factor (Table 1), according to the RFLP patterns of the M. tuberculosis isolates, showed that dwelling in slum communities such as CHP2, Mandela de Pedra, Parque Oswaldo Cruz, Vila Turismo and Nelson Mandela increased the probability of clustering by 4 times in comparison with other communities $(\mathrm{OR}=4.2 ; 95 \% \mathrm{Cl}$ : 0.9-20.9; $\mathrm{p}=0.048$ ), although most of the clustered patients $(11 / 23,47.8 \%)$ were identified in CHP2. Being female correlated strongly with clustering (OR $=6.0 ; 95 \%$ $\mathrm{Cl}: 1.7-21.7 ; p=0.002)$. Although there was no significant association between clustering and drug resistance (OR $=3.4 ; 95 \% \mathrm{Cl}: 0.9-12.8 ; \mathrm{p}=0.069)$, it should be borne in mind that $40 \%$ of the clusters included primary resistant strains, comprising $26 \%$ (6/23) of the clustered patients (Table 2).

The proportion of clustered cases was 34.3\% or $31.3 \%$, depending on whether the strains with only 2 copies are included in the analysis. Strains with a low banding-RFLP genotypic pattern are better discriminated using a secondary typing method such as spoligotyping or mycobacterial interspersed repetitive unit typing ${ }^{(8)}$ neither of which were applied in the present study, since only two patients harbored strains with less than 6 copies of 156110 and had no epidemiological link (Table 2). The number of strains might have been underestimated due to the small sample size and a relatively short study period. Nevertheless, our findings are in accordance with the proportions recently described for transmission in developing countries (20\% to 38\%), although epidemiological information linking clustered patients is usually unavailable. ${ }^{(9-12)}$ The presence of few strains presenting low copy numbers have been described in earlier studies conducted in Brazil as well in other countries. However, a study performed in India showed higher numbers. ${ }^{(10,13)}$ 
Table 1 - Demographic, clinical and microbiological data of patients living in Complexo de Manguinhos, Rio de Janeiro (2000-2002), according to insertion sequence 6110-based restriction fragment length polymorphism clustering.

\begin{tabular}{|c|c|c|c|c|}
\hline Risk Factor & $\begin{array}{c}\text { Cluster } \\
(\mathrm{n}=23)\end{array}$ & $\begin{array}{c}\text { Non-cluster } \\
(\mathrm{n}=44)\end{array}$ & $\begin{array}{c}\text { Odds ratio } \\
(95 \% \mathrm{Cl})\end{array}$ & $p$ \\
\hline Community & & & & 0.048 \\
\hline $\mathrm{CHP}^{*} / \mathrm{MP} / \mathrm{POC} / \mathrm{VT} / \mathrm{NM}$ & 20 & 27 & $4.2(0.9-20.9)$ & \\
\hline Ex-Comb/PCC/PJG/SM/VU & 3 & 17 & 1.0 & \\
\hline \multicolumn{5}{|l|}{ Gender } \\
\hline Male & 9 & 35 & 1.0 & \\
\hline Female & 14 & 9 & $6.0(1.7-21.7)$ & 0.002 \\
\hline \multicolumn{5}{|l|}{ Age (years) } \\
\hline$\leq 30$ & 8 & 24 & 1.0 & \\
\hline$>30$ & 15 & 20 & $2.2(0.1-7.3)$ & 0.200 \\
\hline \multicolumn{5}{|l|}{ Previous treatment } \\
\hline No & 18 & 36 & 1.0 & \\
\hline Yes & 5 & 8 & $1.2(0.3-5.1)$ & 0.752 \\
\hline \multicolumn{5}{|l|}{ HIV status } \\
\hline Negative & 22 & 34 & 1.0 & \\
\hline Positive & 1 & 3 & $0.5(0.1-6.2)$ & 1.000 \\
\hline Unknown & 0 & 7 & & \\
\hline \multicolumn{5}{|l|}{ Sputum smear microscopy } \\
\hline Negative & 4 & 9 & 1.0 & \\
\hline Positive & 19 & 35 & $0.9(0.2-4.4)$ & 1.000 \\
\hline \multicolumn{5}{|l|}{ Drug resistance } \\
\hline Sensitive & 14 & 37 & 1.0 & \\
\hline Resistant & 9 & 7 & $3.4(0.9-12.8)$ & 0.069 \\
\hline Primary & 4 & 2 & & \\
\hline Acquired & 4 & 5 & & \\
\hline MDR & 3 & 5 & & \\
\hline
\end{tabular}

CHP2: Conjunto Habitacional Programado 2; Ex-Comb: Ex-Combatente; MP: Mandela de Pedra; NM: Nelson Mandela; PCC: Parque Carlos Chagas; POC: Parque Oswaldo Cruz; SM: Samora Machel; VT: Vila Turismo; VU: Vila União; and MDR: multidrug resistance. * ${ }^{*} \mathrm{CHP} 2$ accounted for 11 of the 20 clustered patients.

Clinically active TB was predominant in young males in CM. However, there was a significant number of clustered female cases in the present investigation, probably reflecting female confinement in the community, which would lead to greater exposure and transmission. Clustering has been associated with age, previous treatment and acid-fast bacilli (AFB)-positive smears, although epidemiological links have been difficult to establish. ${ }^{(10,13,14)}$ In our study, being infected with a resistant strain and having an AFB-positive smear were not significantly associated with clustering. However, M. tuberculosis isolates were not available for all patients diagnosed in the period. Therefore, there might be a tendency to underestimate the proportion of resistant strains in a given cluster. Although being infected with a resistant strain was not significantly correlated with clustering, it is of note that $40 \%$ of the clusters were involved in the transmission of primary resistance, including multidrug-resistant (MDR) strains (Table 1). The transmission of resistant strains leads to problems related to noncompliance with treatment, reflecting failure on the part of the local TCP. ${ }^{(7)} \mathrm{A}$ similar result in the genotyping of MDR strains was described in a previous study conducted in Brazil. ${ }^{(15)}$ However, the authors of that study found that the occurrence of MDR was significantly associated with previous TB treatment, as well as with TB treatment failure.

One epidemiological study demonstrated that household transmission was associated with $20 \%$ of the clusters, and that $60 \%$ of the clusters were involved in the social chain of transmission, most of them with a potential epidemiological link, as 


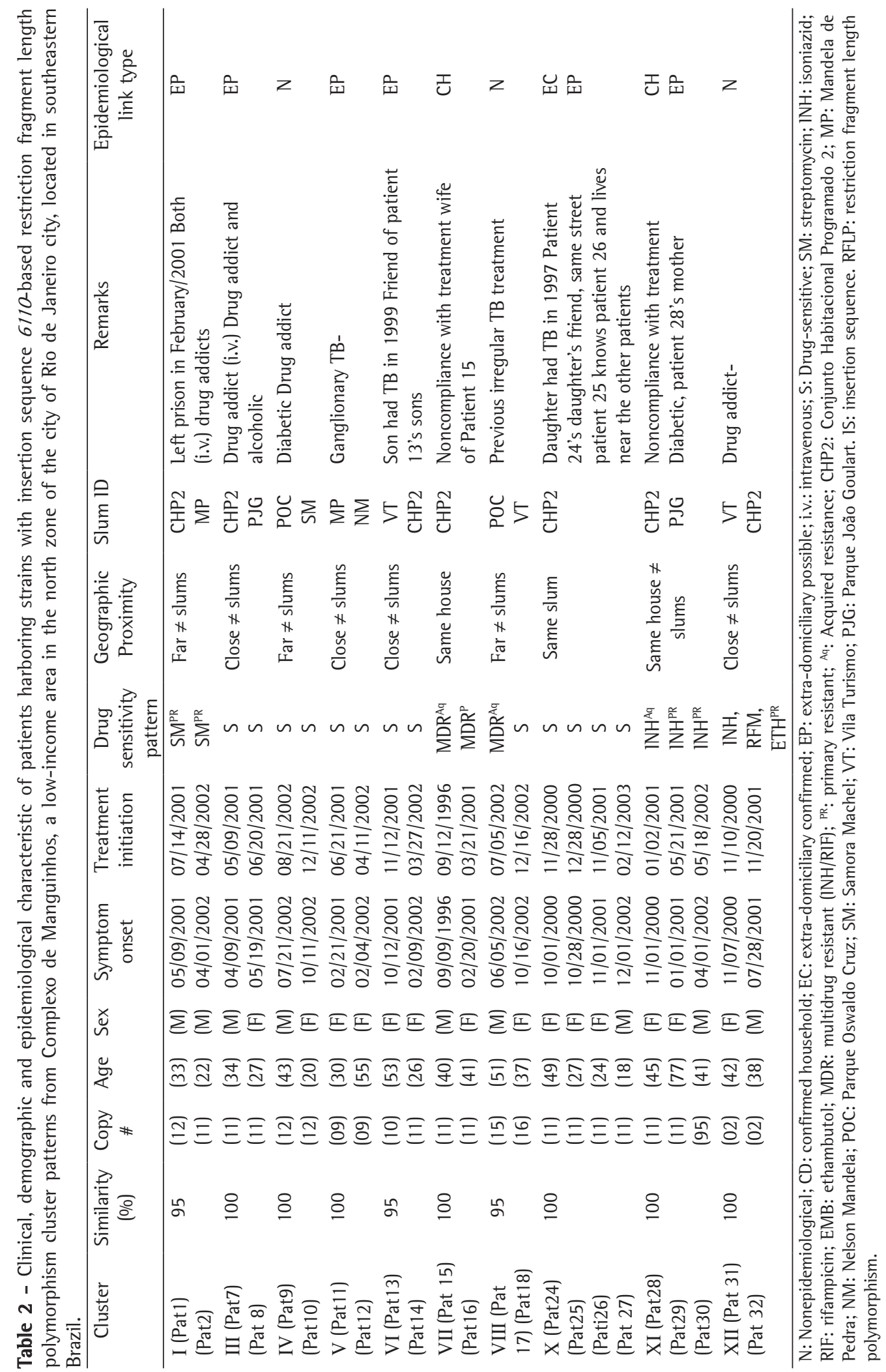


shown in Table 1. Other studies have reported that links could clearly be confirmed only in a small number of the cluster cases, since casual contact is difficult to assess through conventional interview applied in our investigation. ${ }^{(16)}$ In our study, this might have been the case for clusters 111 and V, which comprised patients living in geographic proximity and therefore possibly belonging to a recent chain of transmission, although the index case was not identified.

Recent transmission of strains exhibiting the same genetic pattern, except for one to four bands, has been described, although a single-band change is the most common. ${ }^{(17,18)}$ Clusters I, VI and XI displayed transmission with strains of slightly different patterns, although the link for patients in cluster VI was defined as possible. In cluster XI, a domiciliary link was confirmed for the mother and daughter, and the link was believed to be extradomiciliary for the third patient. Although the link with the institutionalized patient in cluster I might not be clear, since that patient resided geographically far from the others, the patients belong to a common risk group, and the infective strains were primarily resistant. However, there is a possibility that the strain $\left(\mathrm{SM}^{\mathrm{R}}\right)$ might have been imported from the prison to the community. Unfortunately, there have been no RFLP strain genotyping studies involving isolates from inmates in Rio de Janeiro, and is therefore not possible to compare patterns. The other possibility is that the patient was latently infected prior to incarceration and, due to the stress of prison, the disease became active, still being in development when the prisoner was released, resulting in the $\mathrm{SM}^{\mathrm{R}}$ strain being spread throughout the community. Our data, like those of other studies, suggest that cluster analyses based only on identical strains can result in an underestimation of the extent of transmission. ${ }^{(19,20)}$ However, it is also possible that strains with a single-band difference belong to a genotypic family with a narrow variety of patterns. Since we did not recover strains from all TB cases, the patterns obtained represent the situation in a limited group; other patients harboring these banding patterns might have been overlooked, leading to an underestimation of the cluster proportion in CM.

The largest slum (CHP2), with partial sanitary structure (treated water and a sewage system), presented the highest proportion of clustered patients. This is not surprising considering that the people in this crowded community spend most of their time outside, which involves intense contact among the multitude, facilitating transmission. Another area in Rio de Janeiro with similar characteristics (AP-1), as well as similar areas in other countries, has been associated with clustering. However, unlike $\mathrm{CHP} 2, \mathrm{AP}-1$ accounts for higher HIV infection rates among reported cases of TB. ${ }^{(10,14)}$ In the smallest slum, Conjunto Agrícola de Higienópolis (195 inhabitants), there were no TB cases reported during the entire period evaluated..$^{(4,7)}$ The fact that Conjunto Agricola de Higienópolis is isolated from the other slums might have hampered transmission.

In the present study, in addition to the classical transmission among relatives, contact outside the home might have played an important role in overcrowded area transmission. This is supported by our findings related to clusters VI, X and XI, in which at least one of the patients had previous household TB contact. However, the strains in those cases, excluding those in cluster XI, were not available for typing. The other patients included in those clusters had come into contact with the infection, whether that contact was intense or casual, outside the home.

Most of the clusters were composed of only two patients, perhaps due to the failure to recover strains from all patients, leading to missed links with other patients in the $\mathrm{CM}$ chain of transmission. Further studies involving all $M$. tuberculosis-positive cultures obtained over a longer period are needed in order to monitor the evolution of TB transmission in the area. However, one of the principal problems in working in such low-income communities is the urban violence that frequently disrupts communication with the official health facility. ${ }^{(3,7)}$ The present study offers an initial outline of the diversity of M. tuberculosis strains in patients in CM. Although the prevalence might have been underestimated, since strains could not be isolated from all patients, the findings could help improve local TCP strategies.

\section{Acknowledgments}

We thank Selma do Rosário Lima, Chief of the CSEGSF Laboratory, and Dr Luiz Augusto de Araújo Baptista, as well as the Eliana dos Santos Silva, 
Serviço de Estatística, Documentação e Informação em Saúde (SEDIS) health agents Alessandra Rosa, Ary do Carmo, Luciane de Almeida, Riany da Silva Silveira, Simone Marques, Viviane Menezes for providing the patient data information that made this study possible.

\section{References}

1. World Health Organization. Global tuberculosis control: surveillance, planning, financing : WHO report 2005. Geneva: World Health Organization, 2005.

2. Secretaria de Saúde e Defesa Civil do Estado do Rio de Janeiro [Homepage on the Internet]. Rio de Janeiro: Secretaria de Saúde e Defesa Civil do Estado do Rio de Janeiro. [cited 2005 Sep 23]. Tuberculose. Available from: http://www. saude.rj.gov.br/tuberculose/home_tuberc.shtml

3. Mendes JM, Santos MO, Esteves MA, Saad MH, Patroclo MA. Aspectos epidemiológicos da tuberculose no Complexo de Manguinhos, Rio de Janeiro, Brasil. Estudo retrospectivo no período de 1986 a 1994. Pulmão RJ. 2002;11(2):46-50.

4. Mendes JM, Fonseca LS, Lourenço MC, Ferreira RM, Saad $\mathrm{MH}$ A retrospective study of the epidemiological aspects of tuberculosis in the Complexo de Manguinhos, an urban slum area in Rio de Janeiro, Brazil, 2000-2002. J Bras Pneumol. 2007;33(4):443-7.

5. van Embden JD, Cave MD, Crawford JT, Dale JW, Eisenach KD, Gicquel B, et al. Strain identification of Mycobacterium tuberculosis by DNA fingerprinting: recommendations for a standardized methodology. J Clin Microbiol. 1993;31(2):406-9.

6. Saad MH, Fonseca LD, Ferrazoli L, Fandinho F, Palaci M, Grinsztejn B, et al. IS1245 genotypic analysis of Mycobacterium avium isolates from patients in Brazil. Int $\mathrm{J}$ Infect Dis. 1999;3(4):192-6.

7. Mendes JM, Lourenço MC, Ferreira RM, Fonseca LS, Saad $\mathrm{MH}$. Drug resistance in mycobacterium tuberculosis strains isolated from sputum samples from symptomatic outpatients: Complexo de Manguinhos, Rio de Janeiro, Brazil. J Bras Pneumol. 2007;33(5): 579-82.

8. Prodinger WM. Molecular epidemiology of tuberculosis: toy or tool? A review of the literature and examples from Central Europe. Wien Klin Wochenschr. 2007;119(3-4):80-9.

9. Warren R, Hauman J, Beyers N, Richardson M, Schaaf HS, Donald P, et al. Unexpectedly high strain diversity of Mycobacterium tuberculosis in a high-incidence community. S Afr Med J. 1996;86(1):45-9.
10. Oelemann MC, Fontes AN, Pereira MA, Bravin Y, Silva G, Degrave $W$, et al. Typing of Mycobacterium tuberculosis strains isolated in Community Health Centers of Rio de Janeiro City, Brazil. Mem Inst Oswaldo Cruz. 2007;102(4):455-62.

11. Baptista IM, Oelemann MC, Opromolla DV, Suffys PN. Drug resistance and genotypes of strains of Mycobacterium tuberculosis isolated from human immunodeficiency virusinfected and non-infected tuberculosis patients in Bauru, São Paulo, Brazil. Mem Inst Oswaldo Cruz. 2002;97(8):1147-52.

12. Calusni AL, Roscani GN, Villares MC, Soini H, Graviss EA, Ramos Mde C. IS6110 restriction fragment length polymorphism of Mycobacterium tuberculosis isolated from patients with pulmonary tuberculosis in Campinas, Brazil: evidence of intercontinental distribution of strains. Mem lnst Oswaldo Cruz. 2003;98(5):655-8.

13. Narayanan S, Das S, Garg R, Hari L, Rao VB, Frieden TR, et al. Molecular epidemiology of tuberculosis in a rural area of high prevalence in South India: implications for disease control and prevention. J Clin Microbiol. 2002;40(12):4785-8.

14. Verver S, Warren RM, Munch Z, Richardson M, van der Spuy GD, Borgdorff MW, et al. Proportion of tuberculosis transmission that takes place in households in a highincidence area. Lancet. 2004;363(9404):212-4.

15. Valim AR, Possuelo LG, Cafrune Pl, Borges M, Ribeiro MO, Rossetti ML, et al. Evaluation and genotyping of multidrugresistant cases of tuberculosis in southern Brazil. Microb Drug Resist. 2006;12(3):186-91.

16. Van Soolingen D. Molecular epidemiology of tuberculosis and other mycobacterial infections: main methodologies and achievements. J Intern Med. 2001;249(1):1-26.

17. 1ljaz K, Yang Z, Matthews HS, Bates JH, Cave MD. Mycobacterium tuberculosis transmission between cluster members with similar fingerprint patterns. Emerg Infect Dis. 2002;8(11):1257-9.

18. Warren RM, van der Spuy GD, Richardson M, Beyers N, Booysen C, Behr MA, et al. Evolution of the 1S6110-based restriction fragment length polymorphism pattern during the transmission of Mycobacterium tuberculosis. J Clin Microbiol. 2002;40(4):1277-82.

19. Braden CR, Templeton GL, Cave MD, Valway S, Onorato IM, Castro KG, et al. Interpretation of restriction fragment length polymorphism analysis of Mycobacterium tuberculosis isolates from a state with a large rural population. $\mathrm{J}$ Infect Dis. 1997;175(6):1446-52.

20. Bennett DE, Onorato IM, Ellis BA, Crawford JT, Schable $B$, Byers R, et al. DNA fingerprinting of Mycobacterium tuberculosis isolates from epidemiologically linked case pairs. Emerg lnfect Dis. 2002;8(11):1224-9. 